\title{
Intractable progressive pneumocephalus due to tuberculous meningoencephalitis
}

Figure Serial brain CT

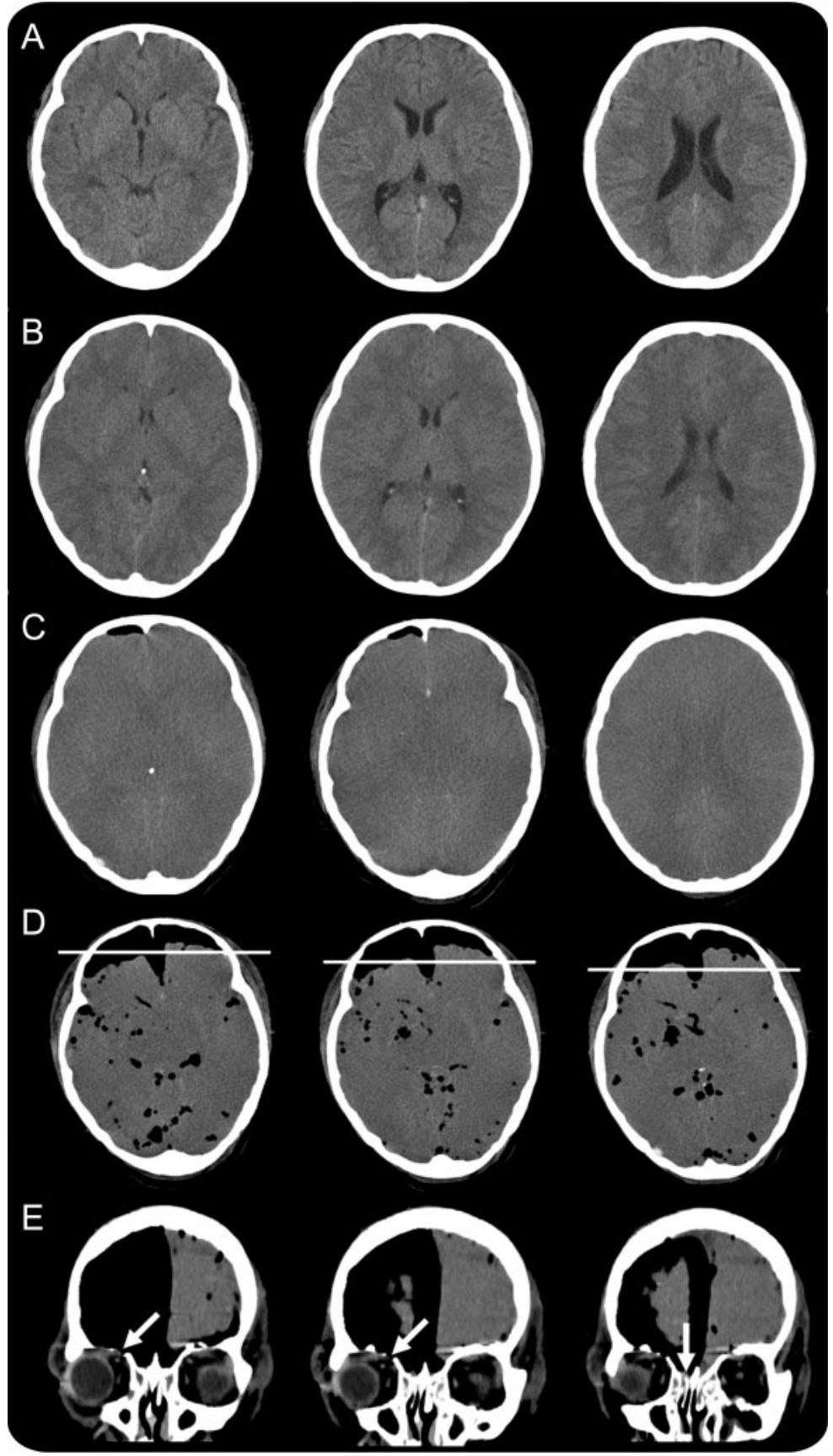

Initial brain CT with no abnormal findings (A). On hospital day 7, mild brain swelling was detected (B), and pneumocephalus with severe brain swelling was noted on day 20 (C). The final brain CT before the patient's death showed marked bony erosion (arrows) with massive pneumocephalus $(D, E)$. The lines on section $D$ represent the coronal plane of below images in section $E$. 
A 25-year-old woman with preexisting systemic lupus erythematosus (SLE) was admitted to the hospital with fever and general fatigue. CSF examination revealed pleocytosis $\left(40 / \mathrm{mm}^{3}\right)$, high protein $(120 \mathrm{mg} / \mathrm{dL})$, and normal adenosine deaminase levels. Despite treatment with antiviral, antibiotic, and antituberculous medications, her mentation deteriorated with severe brain swelling and pneumocephalus (figure). Two weeks later, CSF tuberculous culture was positive without other coinfections detected. Nontraumatic pneumocephalus occurs rarely in tumor invasion and bacterial meningitis. ${ }^{1}$ However, tuberculous meningoencephalitis should be considered in immunocompromised patients such as those with SLE who may develop nontraumatic pneumocephalus. ${ }^{2}$

K.-P. Oh, MD, Y.-J. Lee, MD, S.-C. Bae, MD, W. Baek, MD, Y.S. Kim, MD, H.Y. Kim, MD, Seoul, Republic of Korea

Author contributions: Dr. Oh: drafting/revising the manuscript, study concept or design, analysis or interpretation of data. Dr. Lee: drafting/revising the manuscript, study concept or design, analysis or interpretation of data. Dr. Bae: drafting/revising the manuscript, study concept or design, analysis or interpretation of data. Dr. Baek: drafting/revising the manuscript, study concept or design, analysis or interpretation of data. Dr. Y.S. Kim: drafting/revising the manuscript, analysis or interpretation of data. Dr. H.Y. Kim: drafting/revising the manuscript, study concept or design, analysis or interpretation of data.

Disclosure: The authors report no disclosures.

Address correspondence and reprint requests to Dr. Hyun Young Kim, Department of Neurology, College of Medicine, Hanyang University, 17 Haengdang-dong, Seongdong-gu, Seoul, 133-792, Republic of Korea; hyoungkim1@hanyang.ac.kr

\section{REFERENCES}

1. Schirmer CM, Heilman CB, Bhardwaj A. Pneumocephalus: case illustrations and review. Neurocrit Care 2010;13:152-158.

2. Rock RB, Olin M, Baker CA, Molitor TW, Peterson PK. Central nervous system tuberculosis: pathogenesis and clinical aspects. Clin Microbiol Rev 2008;21:243-261.

\section{NeuroImages Are Free at www.neurology.org!}

All Neurology ${ }^{\circledR}$ NeuroImages can now be freely accessed on the Neurology Web site. See them at www.neurology.org, where you can also sign up for journal email alerts and check out other online features, including the Resident \& Fellow section, Neurology: Clinical Practice, and the weekly Neurology Podcasts. 


\section{Neurology}

Intractable progressive pneumocephalus due to tuberculous meningoencephalitis K.-P. Oh, Y.-J. Lee, S.-C. Bae, et al. Neurology 2011;77;600-601

DOI 10.1212/WNL.0b013e318228c125

\section{This information is current as of August 8, 2011}

\section{Updated Information \& Services}

References

Subspecialty Collections

Permissions \& Licensing

Reprints including high resolution figures, can be found at: http://n.neurology.org/content/77/6/600.full

This article cites 2 articles, 1 of which you can access for free at: http://n.neurology.org/content/77/6/600.full\#ref-list-1

This article, along with others on similar topics, appears in the following collection(s):

CT

http://n.neurology.org/cgi/collection/ct

Encephalitis

http://n.neurology.org/cgi/collection/encephalitis

Meningitis

http://n.neurology.org/cgi/collection/meningitis

Information about reproducing this article in parts (figures,tables) or in its entirety can be found online at:

http://www.neurology.org/about/about_the_journal\#permissions

Information about ordering reprints can be found online:

http://n.neurology.org/subscribers/advertise

Neurology ${ }^{\circledR}$ is the official journal of the American Academy of Neurology. Published continuously since 1951, it is now a weekly with 48 issues per year. Copyright Copyright $@ 2011$ by AAN Enterprises, Inc.. All rights reserved. Print ISSN: 0028-3878. Online ISSN: 1526-632X.

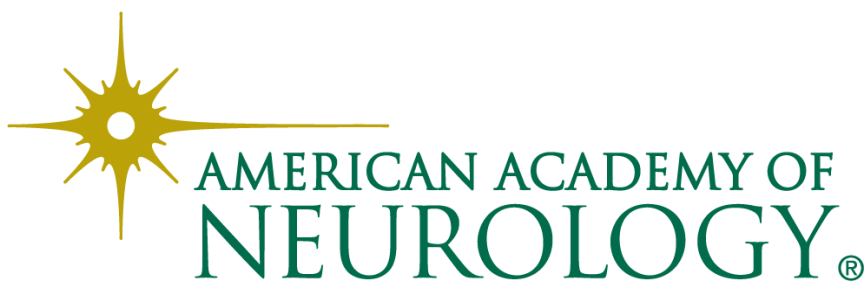

